\title{
THREE NEW IONIC LIQUIDS OF U-SHAPE $N, N$ '-DIALKYLBENZIMIDAZOLIUM SALTS: PREPARATION AND CHARACTERIZATION
}

\author{
KEFEI WANG, FANGFANG JIAN* AND RUIRUI ZHUANG \\ New Materials \& Function Coordination Chemistry Laboratory, Qingdao University of Science and Technology, \\ Qingdao Shandong 266042, P. R. China. \\ (Received: November 11, 2009 - Accepted: January 19, 2010)
}

\begin{abstract}
The present work reports on the synthesis, crystal structures, thermal behaviors and conductivities of three new ionic liquids of $\left[\left(\mathrm{C}_{12} \mathrm{H}_{25}\right)_{2}\right.$-bim $] \mathrm{NO}_{3}(\mathbf{1 a})$, $\left[\left(\mathrm{C}_{8} \mathrm{H}_{17}\right)_{2}\right.$-bim $] \mathrm{HSO}_{4}(\mathbf{1 b})$ and $\left[\left(\mathrm{C}_{10} \mathrm{H}_{21}\right)_{2}\right.$-bim $] \mathrm{ClO}_{4}(\mathbf{1 c})$ (bim=benzimidazole). Their structures were characterized by X-ray crystallography, IR spectroscopy and elemental analysis. The cations of three compounds adopt U-shaped conformations and are packed in a highly interdigitated bilayer fashion. Thermal behaviors were studied by differential scanning calorimetry (DSC). The conductivity of $\mathbf{1 b}$ was lower than $\mathbf{1 a}$ and $\mathbf{1}$. The difference of the conductivity may be attributed to the difference of anion.
\end{abstract}

Keywords: Ionic liquid; Benzimidazole; Crystal structure; Conductivity.

\section{INTRODUCTION}

Ionic liquids (ILs) are attracting considerable attention as versatile media and materials due to their peculiar physicochemical properties. ${ }^{1-4}$ Ionic liquids are characterized by extremely low vapor pressures, wide liquid ranges, nonflammability, thermal stability, tunable polarity, good electrolytic properties, and easy recycling. ${ }^{5}$ ILs with different cations have been described in the literature, such as ammonium, phosphonium, pyridinium, and imidazolium salts. ${ }^{1-4}$ Among these, imidazolium salts are some of the most frequently studied. ${ }^{1-4,6}$ This is due to the use of imidazolium salts as ligand precursors in the synthesis of metal-carbene complexes, ${ }^{7-10}$ which are excellent catalysts in many chemical reactions ${ }^{11}$. Dibrov et al. reported the crystal structure of [bmim] $\mathrm{PF}_{6}($ bmim $=1$-butyl-3-methyl-imidazolium $) .{ }^{12}$ Henderson et al. reported the crystal structures and thermal behaviors of the 1-(2-methoxyethyl)-2,3dimethylimidazolium chloride and hexafluorophosphate salts. ${ }^{13}$ Dobbs et al. reported ionic liquid crystals based on 1-(4-dodecyloxybenzyl)-3-methyl-1Himidazol-3-ium salts, various salts containing $\mathrm{Br}^{-}, \mathrm{BF}_{4}^{-}, \mathrm{SCN}^{-}, \mathrm{PF}_{6}^{-}, \mathrm{CF}_{3} \mathrm{SO}_{3}^{-}$, $\left(\mathrm{CF}_{3} \mathrm{SO}_{2}\right)_{2} \mathrm{~N}^{-14}$

Benzimidazolium as derivatives of imidazolium may possess the most nice properties of imidazolium. Furthermore, the ILs of N,N'-benzimidazolium salts using in catalytic systems increasingly arouses great attention. ${ }^{14-17}$ However, only several crystal structures of 1,3-dialkylbenzimidazolium chlorides and bromides have been reported. ${ }^{18,19}$ To best of our knowledge, reports on the corresponding benzimidazolium with different anions are lacking, and the study of short $\mathrm{C}-\mathrm{H} \cdots \mathrm{O}$ contact in ionic liquids are even scarce..$^{18}$ The significance of our work is to report the synthesis, structures, thermal behaviors and conductivities of $\left[\left(\mathrm{C}_{12} \mathrm{H}_{25}\right)_{2}\right.$-bim $] \mathrm{NO}_{3},\left[\left(\mathrm{C}_{8} \mathrm{H}_{17}\right)_{2}\right.$-bim $] \mathrm{HSO}_{4}$ and $\left[\left(\mathrm{C}_{10} \mathrm{H}_{21}\right)_{2}\right.$ bim $] \mathrm{ClO}_{4}$. Additionally, we pay particular attention to the short $\mathrm{C}-\mathrm{H} \cdots \mathrm{O}$ contacts in the molecules.

\section{EXPERIMENTAL SECTION}

\subsection{Materials and methods}

All the chemicals were of analytical reagent grade and used without further purification. Elemental compositions were measured with a PerkinElmer 1400C analyzer (USA). Infrared spectra were recorded on a Nicolet 170SX spectrometer (USA) using pressed $\mathrm{KBr}$ plates in the $4000-400 \mathrm{~cm}^{-1}$ ranges. Crystal structures determination by X-ray diffraction were performed on a Bruker-Nonius diffractometer with Kappa geometry attached with an APEX-CCD detector (Bruker, Germany). Phase transition temperatures were determined using a Netzsch DSC 204 thermal analysis data station at a scan rate of $10^{\circ} \mathrm{C} \mathrm{min}{ }^{-1}$. Conductivity measurements were performed using DZS707 multi-parameter water quality analysis instrument (Shanghai Precision \& Scientific Instrument Co. Ltd.).

2.2. Synthesis

Synthesis of $\left[\left(\mathrm{C}_{12} \mathrm{H}_{25}\right)_{2}-\right.$ bim $] \mathrm{NO}_{3}$ (1a)

$\mathrm{N}, \mathrm{N}$-dialkylbenzimidazolium bromide was obtained according to the literature. ${ }^{19}$ Silver nitrate $(96.9 \mathrm{mg}, 0.57 \mathrm{mmol})$ was dissolved in water $(15$ $\mathrm{mL})$. To this solution, N,N'-dialkylbenzimidazolium bromide $(307 \mathrm{mg}, 0.57$ mmol) in ethanol solution $(30 \mathrm{~mL})$ was added. The resultant solution was stirred under refluxing for $3 \mathrm{~h}$ and white precipitate appeared. The resulting solid was filtered and moved, while solvent was evaporated to afford colorless crystals (mp 123-125 ${ }^{\circ}$ ), $231 \mathrm{mg}$, Yield: $78 \%$. Anal. Calcd. for $\mathrm{C}_{31} \mathrm{H}_{57} \mathrm{~N}_{3} \mathrm{O}_{3}$ : C, 71.63; H, 11.05; N, 8.08\%. Found: C, 71.59; H, 11.12; N, 8.11\%. Main IR bands $\left(\mathrm{KBr}, \mathrm{cm}^{-1}\right): 3103 \mathrm{~s}, 2919 \mathrm{~s}, 2851 \mathrm{~s}, 1560 \mathrm{~m}, 1467 \mathrm{~s}, 1428 \mathrm{~s}, 1339 \mathrm{vs}, 829 \mathrm{~s}$.

The following1,3-dialkylbenzimidazolium compounds were prepared by a method similar to that of $\mathbf{1 a}$.

$\left[\left(\mathrm{C}_{8} \mathrm{H}_{17}\right)_{2}\right.$-bim] $\mathrm{HSO}_{4}(\mathbf{1 b}) .\left(\mathrm{mp} 205-208^{\circ} \mathrm{C}\right)$ Anal. Calcd. for $\mathrm{C}_{23} \mathrm{H}_{41} \mathrm{~N}_{2} \mathrm{O}_{4} \mathrm{~S}$ : $\mathrm{C}, 62.55 ; \mathrm{H}, 9.36$; N $6.34 ; \mathrm{S}, 7.26 \%$. Found: $\mathrm{C}, 63.48 ; \mathrm{H}, 9.36 ; \mathrm{N}, 6.39 ; \mathrm{S}$, $7.18 \%$. Main IR bands $\left(\mathrm{KBr}, \mathrm{cm}^{-1}\right): 3080 \mathrm{~m}, 2918 \mathrm{~s}, 2849 \mathrm{~s}, 1562 \mathrm{~m}, 1468 \mathrm{~m}$, $1160 \mathrm{~m}, 1027 \mathrm{~s}$.

$\left[\left(\mathrm{C}_{10} \mathrm{H}_{21}\right)\right.$-bim $] \mathrm{ClO}_{4}(\mathbf{1 c}) .\left(\mathrm{mp} 113-115^{\circ} \mathrm{C}\right)$ Anal. Calcd. for $\mathrm{C}_{27} \mathrm{H}_{47} \mathrm{ClN}_{2} \mathrm{O}_{4}$ : C, 64.97; H, 9.49; N, 5.61\%. Found: C, 64.95; H, 9.42; N, 5.69\%. Main IR bands $\left(\mathrm{KBr}, \mathrm{cm}^{-1}\right): 3071 \mathrm{~m}, 2920 \mathrm{~s}, 2851 \mathrm{vs}, 1562 \mathrm{vs}, 1468 \mathrm{~s}, 1427 \mathrm{vs}, 1096 \mathrm{~s}$.

2.3. X-Ray Crystallography

Diffraction intensities were collected on a Bruker APEX-CCD areadetector diffractometer (Mo $K_{\alpha}, \lambda=0.71073 \AA$ ) at $20^{\circ} \mathrm{C}$. Their structures were solved by direct methods and refined by least squares on $F^{2}{ }^{2}$ by using the SHELXTL software package. ${ }^{20}$ All nonhydrogen atoms were refined anisotropically, and the hydrogen atoms were placed in calculated position and allowed to ride on their parent atoms. The molecular graphics and crystal stacking were plotted using the SHELXTL. Atomic scattering factors and anomalous dispersion corrections were taken from the International Tables for X-ray Crystallography. ${ }^{21}$

\section{RESULTS AND DISCUSSION}

\subsection{Crystal structures of three compounds}

Crystal data and structure refinement of 1a-1c are listed in Table 1. The crystal structure of 1a is given in Fig. 1(a). The molecular cation adopts a U-shaped conformation, in which the geometry looks like a two-leg stool. The two-alkyl chains in the cation run perpendicular to the benzimidazolium core plane in a same orientation, which is similar to that found in the N,N'dialkylbenzimidazolium bromide. ${ }^{8}$ The angles of alkyl chains are $84.05^{\circ}$ and $83.27^{\circ}$ with the two arms pointing in the same direction. Each plane of benzimidazolium connects side by side to the neighbouring molecules through $\mathrm{C}-\mathrm{H} \cdots \mathrm{O}$ hydrogen bonds, such that the aromatic rings line up in a row with all the legs pointing in the same direction [Fig.1(b)]. Each row further connects with the other through hydrogen bonds to form a plane, like a tiled roof and again with all the legs pointing in the same direction. Interdigitation of two such planes with interpenetrating alkyl chains generate a bilayer of $17.4 \AA$ thickness. The benzimidazolium cations are packed in a head-to-head fashion. The flat benzimidazole ring heads align parallel to the neighboring flat heads but face those of an opposing layer.

As we know, non-covalent interactions are at the core of most chemical and biological processes and hence knowledge of their nature, strength, occurrence and consequences is of paramount importance. ${ }^{16}$ The weak non-covalent interactions such as $\mathrm{C}-\mathrm{H} \cdots \mathrm{X}(\mathrm{X}=\mathrm{O}, \mathrm{N}, \mathrm{S}$, halogen $), \pi-\pi$ stacking, while 
weaker than the classical H-bonds, also play notable roles in conformation, crystal packing, supramolecular assembly and physicochemical properties and thus have implications in drug design, material design and supramolecular synthesis. ${ }^{15-17}$ There are some weak potentially $\mathrm{C}-\mathrm{H} \cdots \mathrm{O}$ hydrogen bonds intermolecular interactions, and the donor-acceptor distances are $\mathrm{C}(24) \cdots \mathrm{O}(2)$ $3.37 \AA, \mathrm{C}(25) \cdots \mathrm{O}(2) 3.05 \AA, \mathrm{C}(25) \cdots \mathrm{O}(3) 3.26 \AA, \mathrm{C}(27) \cdots \mathrm{O}(1) 3.25 \AA$, $\mathrm{C}(27) \cdots \mathrm{O}(3) 3.38 \AA$ and $\mathrm{C}(30) \cdots \mathrm{O}(2) 3.21 \AA$, respectively. The $\mathrm{H} \cdots \mathrm{O}$ distances are in the range of 2.2-2.59 $\AA$. The anions are not in the proximity of the positively charged $\mathrm{N}$ atoms, rather, each anion forms hydrogen bonds with four $\mathrm{C}-\mathrm{H}$ groups $[\mathrm{H}(24 \mathrm{~B}), \mathrm{H}(25 \mathrm{~A}), \mathrm{H}(27 \mathrm{~A})$ and $\mathrm{H}(30 \mathrm{~A})]$ from three neighbouring benzimidazole planes. If one consideres each alkyl chain as a rod, the rods exhibite hexagonal close-packing and the distances between the neighbouring rods are in the range of 4.1-4.6 $\AA$. There are four types of $\pi-\pi$ stacking interactions between imidazole rings and phenyl rings. The center-tocenter distances are in the range of 3.413 to $3.628 \AA$. The shortest interplanar distances above are in the range of 3.341 to $3.413 \AA$.

Table 1: Crystal data and structure refinement for 1a-1c.

\begin{tabular}{|c|c|c|c|}
\hline Structure parameter & $1 \mathrm{a}$ & $1 b$ & $1 \mathrm{c}$ \\
\hline Empirical formula & $\mathrm{C}_{31} \mathrm{H}_{55} \mathrm{~N}_{3} \mathrm{O}_{3}$ & $\mathrm{C}_{23} \mathrm{H}_{41} \mathrm{~N}_{2} \mathrm{O}_{4} \mathrm{~S}$ & $\mathrm{C}_{27} \mathrm{H}_{47} \mathrm{ClN}_{2} \mathrm{O}_{4}$ \\
\hline Formula weight & 517.78 & 441.64 & 499.12 \\
\hline Temperature (K) & 293(2) & 293(2) & 293(2) \\
\hline Wavelength $(\AA)$ & 0.71073 & 0.71073 & 0.71073 \\
\hline Crystal system, & Orthorhombic & Triclinic & Triclinic \\
\hline Space group & Pbca & $P \bar{l}$ & $P \bar{l}$ \\
\hline \multicolumn{4}{|l|}{ Unit cell dimensions } \\
\hline$a(\AA)$ & $9.344(5)$ & $9.042(2)$ & $9.567(5)$ \\
\hline$b(\AA)$ & 16.682(9) & $9.534(2)$ & $10.123(5)$ \\
\hline$c(\AA)$ & $41.32(2)$ & 16.071(3) & $17.848(9)$ \\
\hline$\alpha\left({ }^{\circ}\right)$ & 90 & $98.845(3)$ & $76.39(1)$ \\
\hline$\beta\left({ }^{\circ}\right)$ & 90 & $94.685(3)$ & $80.63(1)$ \\
\hline$\gamma\left({ }^{\circ}\right)$ & 90 & $107.156(3)$ & 63.231(9) \\
\hline Volume $\left(\AA^{3}\right)$ & 6441(6) & 1296.1(4) & 1497(1) \\
\hline $\begin{array}{l}\text { Z, Calculated density (g } \\
\mathrm{cm}^{-3} \text { ) }\end{array}$ & $8,1.068$ & $2,1.132$ & $2,1.108$ \\
\hline $\begin{array}{l}\text { Absorption coefficient } \\
\left(\mathrm{mm}^{-1}\right)\end{array}$ & 0.068 & 0.153 & 0.159 \\
\hline$F(000)$ & 2288 & 482 & 544 \\
\hline $\begin{array}{l}\text { Theta range for data } \\
\text { collection }\left({ }^{\circ}\right)\end{array}$ & 1.97 to 25.00 & 1.77 to 28.34 & 2.29 to 28.27 \\
\hline $\begin{array}{l}\text { Reflections collected / } \\
\text { unique }\end{array}$ & $\begin{array}{l}31011 / 5645 \\
{\left[R_{(\mathrm{int})}=0.1349\right]}\end{array}$ & $\begin{array}{l}8383 / 5949 \\
{\left[R_{\text {(int) }}=0.0988\right]}\end{array}$ & $\begin{array}{l}9798 / 6892 \\
{\left[R_{\text {(int) }}=\right.} \\
0.0393]\end{array}$ \\
\hline Completeness (\%) & 99.8 & 91.3 & 92.7 \\
\hline $\begin{array}{l}\text { Data / restraints / } \\
\text { parameters }\end{array}$ & $5645 / 0 / 335$ & $5949 / 0 / 272$ & $6892 / 0 / 307$ \\
\hline Goodness-of-fit on $F^{2}$ & 1.016 & 1.043 & 0.925 \\
\hline Final $R$ indices $[I>2 s(I)]$ & $\begin{array}{l}R_{1}=0.1046 \\
\mathrm{w} R_{2}=0.2522\end{array}$ & $\begin{array}{l}R_{1}=0.0806 \\
w R_{2}=0.2338\end{array}$ & $\begin{array}{l}R_{1}=0.0694 \\
w R_{2}=0.1824\end{array}$ \\
\hline$R$ indices (all data) & $\begin{array}{l}R_{1}=0.2830 \\
\mathrm{w} R_{2}=0.3537\end{array}$ & $\begin{array}{l}R_{1}=0.1787 \\
w R_{2}=0.2947\end{array}$ & $\begin{array}{l}R_{1}=0.2148 \\
w R_{2}=0.2540\end{array}$ \\
\hline $\begin{array}{l}\text { Largest diff. peak and hole } \\
\left(\mathrm{e} \AA^{-3}\right)\end{array}$ & $\begin{array}{l}0.218 \text { and } \\
0.198\end{array}$ & $\begin{array}{l}0.607 \text { and } \\
0.371\end{array}$ & \begin{tabular}{|l}
0.261 and \\
0.193
\end{tabular} \\
\hline
\end{tabular}

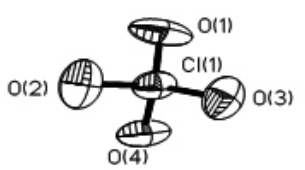

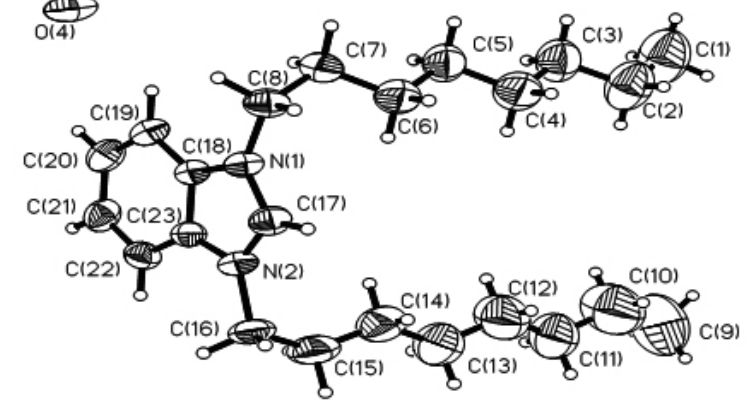

Figure 1(a). The molecular structure of $\mathbf{1 a}$ with the atomic numbering scheme.

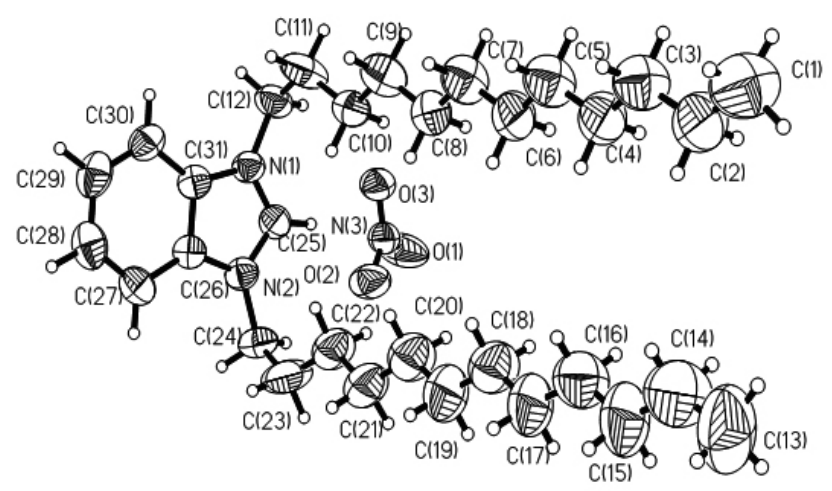

Figure 1(b). Stacking of the bilayered structure of 1a.

The molecular structure of $\mathbf{1 b}$ with the atomic numbering scheme is shown in Fig. 2(a). The bond lengths, bond angles and the conformation of the cation are similar to those of 1a. Each plane of benzimidazolium connects side by side to the neighbouring molecules through $\mathrm{C}-\mathrm{H} \cdots \mathrm{O}$ hydrogen bonds, such that the aromatic rings line up in a row with all the legs pointing in the same direction [Fig. 2(b)]. Interdigitation of two such planes with interpenetrating alkyl chains generate a bilayer of $14.3 \AA$ thickness. The benzimidazolium cations are packed in a head-to-head fashion. There are some weak potentially $\mathrm{C}-\mathrm{H} \cdots \mathrm{O}$ hydrogen bonds intermolecular interactions, and the donor-acceptor distances are in the range of 3.08-3.45 $\AA$, for $\mathrm{C}(8) \cdots \mathrm{O}(1) 3.4588 \AA, \mathrm{C}(17) \cdots \mathrm{O}(1) 3.3271$ $\AA, \mathrm{C}(17) \cdots \mathrm{O}(4) 3.0816 \AA, \mathrm{C}(22) \cdots \mathrm{O}(1) 3.2943 \AA$. There are two types of $\pi-\pi$ stacking interactions between imidazole rings and phenyl rings. The centerto-center distances are $3.5182 \AA$. The shortest interplanar distances above are 3.498 and $3.505 \AA$.

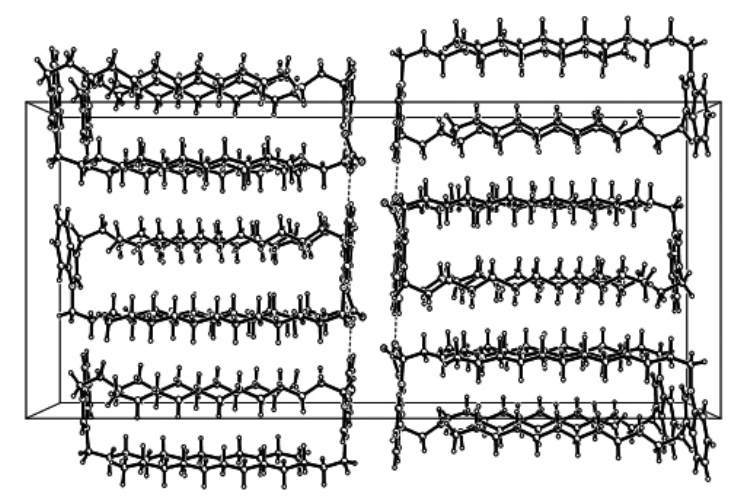

Figure 2(a). The molecular structure of $\mathbf{1 b}$ with the atomic numbering scheme. 


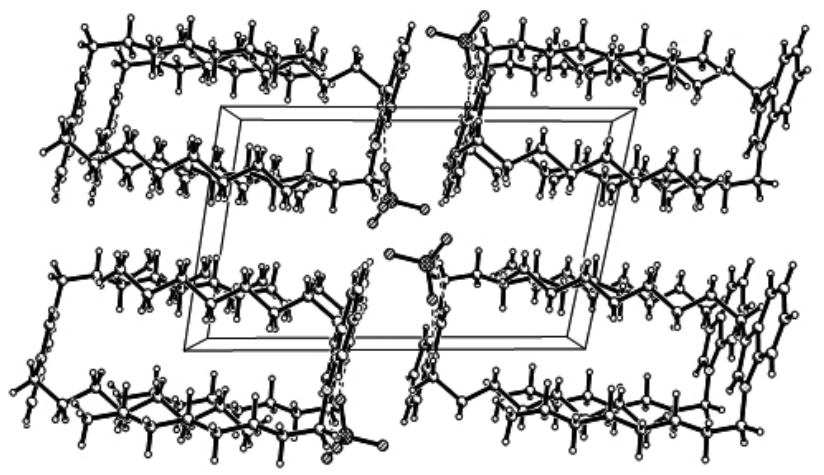

Figure 2(b). Stacking of the bilayered structure of $\mathbf{1 b}$.

The molecular structure of $\mathbf{1 c}$ with the atomic numbering scheme is shown in Fig. 3(a). The space group of the $\mathbf{1 c}$ is identical to that of $\mathbf{1 b}$. The bond lengths, bond angles and the conformation of the cation are similar to those of $1 \mathbf{a}$ and $\mathbf{1 b}$. Each plane of benzimidazolium connects side by side to the neighbouring molecules through $\mathrm{C}-\mathrm{H} \cdots \mathrm{O}$ hydrogen bonds, such that the aromatic rings line up in a row with all the legs pointing in the same direction [Fig. 3(b)]. Interdigitation of two such planes with interpenetrating alkyl chains generate a bilayer of $17.1 \AA$ thickness. The benzimidazolium cations are packed in a head-to-head fashion. There are some weak potentially $\mathrm{C}-\mathrm{H} \cdots \mathrm{O}$ hydrogen bonds intermolecular interactions, and the donor-acceptor distances are in the range of 3.25-3.35 $\AA$, for $\mathrm{C}(21) \cdots \mathrm{O}(3) 3.3531 \AA, \mathrm{C}(21) \cdots \mathrm{O}(4) 3.2909$ $\AA$ and $\mathrm{C}(26) \cdots \mathrm{O}(4) 3.2618 \AA$, respectively. There are two types of $\pi$ - $\pi$ stacking interactions between imidazole rings and phenyl rings. The center-to-center distances are in the range of 3.5566 to $3.6875 \AA$. The shortest interplanar distances above are in the range of 3.429 to $3.483 \AA$.

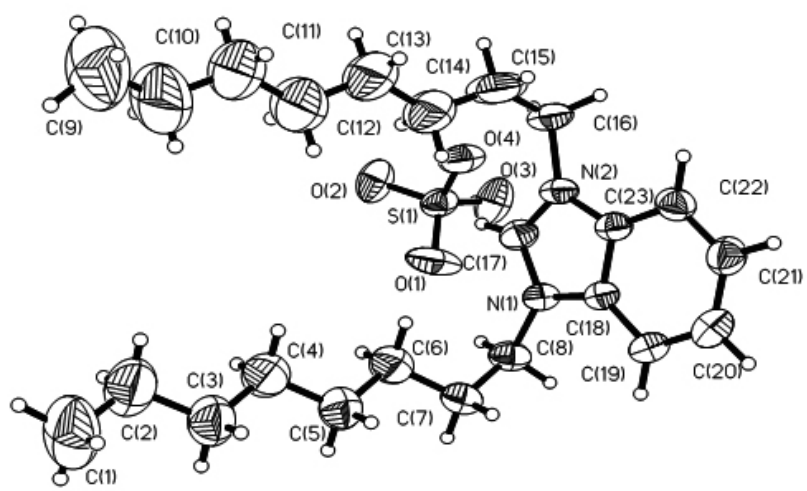

Figure 3(a). The molecular structure of $1 \mathbf{c}$ with the atomic numbering scheme.

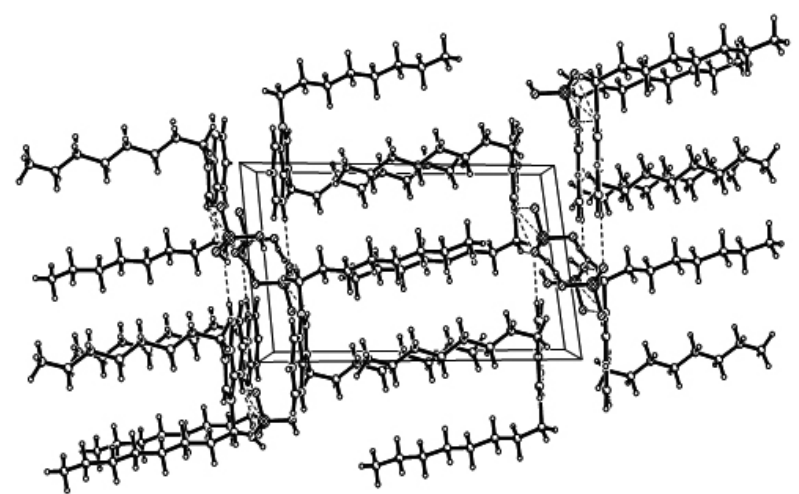

Figure 3(b). Stacking of the bilayered structure of 1c.
3.2. Thermal behavior

For three compounds, the thermal behaviors and phase transition temperatures were investigated by differential scanning calorimetry (DSC). DSC was performed in air at a heating rate of $10^{\circ} \mathrm{C} \mathrm{min}^{-1}$. To avoid possible effects of hydration of the materials, three compounds were dried under vacuum before DSC analysis. The phase transition temperature and the corresponding enthalpy changed derived for compounds 1a-1c were displayed in Fig. 4. Compounds 1a and 1c just exhibited one endothermic transition in the first heating cycle at $123.9^{\circ} \mathrm{C}$ and $114.8^{\circ} \mathrm{C}$ with a total $\Delta \mathrm{H}$ value of $239.3 \mathrm{~kJ}$ $\mathrm{mol}^{-1}, 121.9 \mathrm{~kJ} \mathrm{~mol}^{-1}$, respectively. Compound $\mathbf{1 b}$ exhibited two endothermic transitions in the heating cycle. For $\mathbf{1 b}$ the first transition was one peak with a total $\Delta \mathrm{H}$ value of $30.9 \mathrm{~kJ} \mathrm{~mol}^{-1}$ at $53.0^{\circ} \mathrm{C}$, and the second transition peak had a $\Delta \mathrm{H}$ value of $131.6 \mathrm{~kJ} \mathrm{~mol}^{-1}$ at $207.7^{\circ} \mathrm{C}$. The first peak corresponded to the transition of one crystal phase to another. The second peak, having a relatively big $\Delta \mathrm{H}$ value, corresponded to the transition of crystal phase to isotropic liquid. The subsequent cooling and heating processes can give reproducible results.

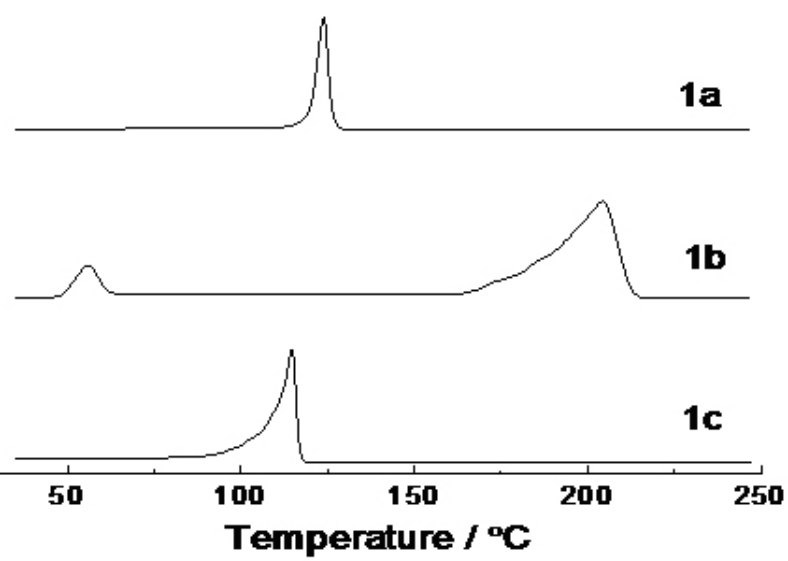

Figure 4. Differential scanning calorimetry result curves of 1a-1c.

\subsection{Conductivity}

Because the melting points of $\mathbf{1 a - 1 c}$ were relatively high, it was difficult to study their conductivities by pure compounds according to VTF-type (Vogel-Tamman-Fulcher) equation..$^{22}$ As a result, it had to be studied in ethanol solution. The conductivities of $1 \times 10^{-3} \mathrm{M} 1 \mathrm{a}-1 \mathrm{c}$ were measured using a conventional conductivity cell as described below (Fig. 5). In order to elucidate the conductivities of three compounds were measured in ethanol solution from $30^{\circ} \mathrm{C}$ to $85^{\circ} \mathrm{C}$. The conductivities of three compounds increased with the temperature increasing. The conductivities were almost proportional to the temperature, in which conductivities of $1 \mathbf{a}$ and $1 \mathbf{c}$ were similar below $60^{\circ} \mathrm{C}$, but the conductivity of $1 \mathrm{c}$ increased faster than $1 \mathrm{a}$ above $60^{\circ} \mathrm{C}$ with the temperature increasing. The conductivity of $\mathbf{1 b}$ was lower than $\mathbf{1 a}$ and $\mathbf{1} \mathbf{c}$. The difference of the conductivity may be attributed to the difference of anion.

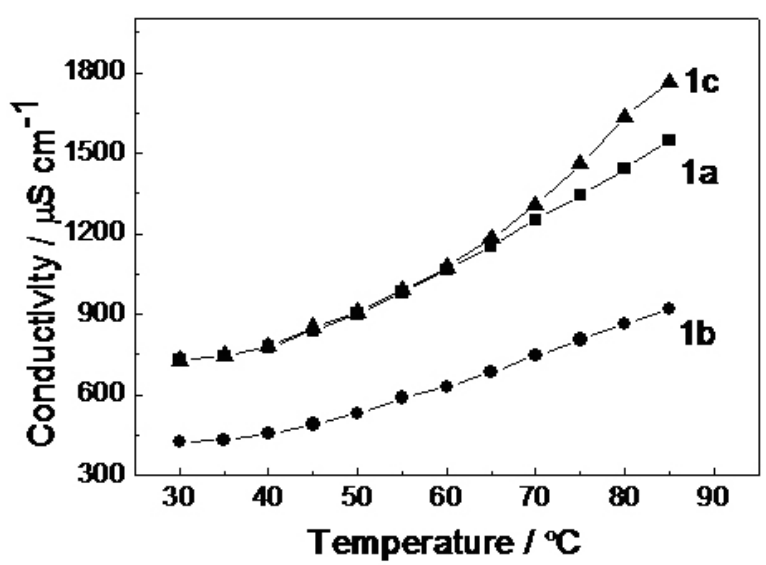

Figure 5. Curves of conductivities of $1 \times 10^{-3} \mathrm{M} \mathbf{1 a}-\mathbf{1 c}$ in ethanol solution with temperature increasing. 


\section{CONCLUSIONS}

In this work we have prepared three new ionic liquids composed of $N, N^{\prime}$ Dialkyl benzimidazolium salts $\left[\left(\mathrm{C}_{12} \mathrm{H}_{25}\right)_{2}-\right.$ bim $] \mathrm{NO}_{3},\left[\left(\mathrm{C}_{8} \mathrm{H}_{17}\right)_{2}\right.$-bim $] \mathrm{HSO}_{4}$ and $\left[\left(\mathrm{C}_{10} \mathrm{H}_{21}\right)_{2}\right.$-bim $] \mathrm{ClO}_{4}$. The anions are intercalated between the hydrophobic bilayers composed of U-shaped benzimidazolium cations with highly interdigitated alkyl chains. All the molecules are packed through $\mathrm{C}-\mathrm{H} \cdots \mathrm{O}$ hydrogen bonds contacts. The hydrogen bonds and stacking interactions are similar, so the difference of melting pionts and $\Delta \mathrm{H}$ values may cause by molecular weight and Van der Waals interactions. The conductivity of $\mathbf{1 b}$ was lower than 1a and 1c. The difference of the conductivity may be attributed to the difference of anion. On the basis of their properties, the new ionic liquid materials may have potential applications as optoelectronic materials, thermal storage media, supporting electrolyte, or ordered reaction media.

\section{ACKNOWLEDGEMENT}

This work was supported by the Natural Science Foundation of Shandong Province (No.Z2007B01), P. R. China.

\section{Supplementary material}

Crystallographic data of the structural analysis have been deposited at the Cambridge Crystallographic Data Centre, CCDC reference number 692254 747919 and 747920 . Copies of this information can be obtained free of charge from The Director, 12 Union Road, Cambridge, CB2 1EZ, UK (fax: +44-1223336033; e-mail: deposit@ccdc.cam.ac.uk or http://www.ccdc.cam ac.uk).

\section{REFERENCES}

1. T. Welton, Chem. Rev. 99, 2071, (1999).

2. P. Wasserscheid, W. Keim, Angew. Chem. Int. Ed. 39, 3772, (2000).

3. R. Sheldon, Chem. Commun. 2399, (2001).
4. J. Dupont, R.F. de Souza, P.A.Z. Suarez, Chem. Rev. 102, 3667, (2002).

5. J. Ranke, S. Stolte, R. Stormann, J. Arning, B. Jastorff, Chem. Rev. 107, 2183, (2007).

6. I.J.B. Lin, C.S. Vasam, J. Organomet.Chem. 690, 3498, (2005).

7. D. Bourissou, O. Guerret, F.P. Gabbai, G. Bertrand, Chem. Rev. 100, 39, (2000).

8. W.A. Herrmann, Angew. Chem. Int. Ed. 41, 1290, (2002).

9. C.M. Crudden, D.P. Allen, Chem. Rev. 248, 2247, (2004).

10. N.M. Scott, S.P. Nolan, Eur. J. Inorg. Chem. 2005, 1815, (2005).

11. B. Cornils, W.A. Herrmann, in: Wiley-VCH: Weinheim: 2002.

12. S.M. Dibrov, J.K. Kochi, Acta Cryst. C62, o19, (2006).

13. W.A. Henderson, V.G. Young, Jr., D.M. Fox, H.C. De Long, P.C. Trulove, Chem. Commun. 3708, (2006).

14. W. Dobbs, L. Douce, L. Allouche, A. Louati, F. Malboscd, R. Weltere, New J. Chem., 30, 528 (2006).

15. W. Huang, J. Guo, Y. Xiao, M. Zhu, G. Zou, J. Tang, Tetrahedron 61, 9783, (2005).

16. K. Iwamoto, M. Hamaya, N. Hashimoto, H. Kimura, Y. Suzukia, M. Satoa, Tetrahedron Lett. 47, 7175, (2006).

17. V.I. Parvulescu, C. Hardacre, Chem. Rev. 107, 2615, (2007).

18. K.M. Lee, C.K. Lee, I.J.B. Lin, Chem. Commun. 899, (1997).

19. N. Kuhn, M. Walker, M. Steimann, Z. Naturforsch. B57, 248, (2002).

20. G.M. Sheldrick, SHELXTL 6.10, Bruker Analytical Instrumentation, Madison, WI, 2000.

21. A.J. Wilson, International Table for X-ray Crystallography, V. C, Kluwer Academic Publishers, Dordrecht, 1992.

22. J. Vila, P. Ginés, J. M. Pico, C. Franjo, E. Jiménez, L. M. Varela, O. Cabeza, Fluid Phase Equilib. 242, 141, (2006). 